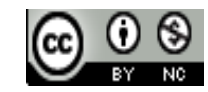

Jurnal Bimbingan Konseling Indonesia is licensed under

A Creative Commons Attribution-Non Commercial 4.0 International License.

\title{
LAYANAN BK MELALUI APLIKASI PERMAINAN TRADISIONAL LOMPAT TALI TERHADAP SIKAP KERJA SAMA
}

\author{
Iip Istirahayu ${ }^{1)}$ \\ 1) STKIP Singkawang, Singkawang, Indonesia \\ E-mail: iip_istirahayu@yahoo.com
}

\begin{abstract}
Abstrak. Munculnya permainan modern menyebabkan tergeser dan hilangnya permainan tradisional, sehingga salah satu upaya yang dilakukan adalah Pengaplikasian permainan tradisional dalam Pendidikan melalui bimbingan dan konseling. Tujuan dari pengaplikasian permainan tradisional lompat tali adalah untuk melihat sikap kerjasama siswa Sekolah Dasar (SD). Metode penelitian yang digunakan adalah metode penelitian kualitatif dengan menggunakan instrument observasi pada 50 kelompok (1 kelompok 5 orang). Hasil penelitian menjelaskan bahwa adanya kerjasama yang baik, hal ini terlihat dari siswa memiliki tujuan yang sama dalam mencapai tujuan, terlihat sikap saling membatu, adanya sikap mentaati aturan permainan, adanya saling komunikasi antar anggota kelompok, memiliki rasa tanggung jawab kebersamaan, saling membaur satu sama lain tanpa memandang perbedaan, adanya pembagian tugas dalam kelompok.
\end{abstract}

Kata Kunci: Permainan Tradisional; Lompat Tali; Kerjasama

\section{Pendahuluan}

Indonesia merupakan salah satu negara yang mempunyai kebudayaan yang sangat beraneka ragam. Indonesia kaya akan seni kebudayaan yang terdapat disetiap daerah atau wilayah masing-masing. Terdapat berbagai macam kekayaan yang dimiliki Indonesia seperti makanan khas tradisional, tarian tradisional, pakaian tradisional serta permainan tradisional dan lain sebagainya. Permainan tradisional adalah salah satu wujud atau bentuk kebudayaan.

Bermain bukan hanya untuk kesenangan semata, tetapi juga sebagai suatu kebutuhan yang harus terpenuhi. Melalui kegiatan bermain, anak dapat sekaligus belajar pada lingkungan sekitarnya sehingga anak tidak hanya mengenal lingkungan rumah saja. Saat bermain, anak-anak akan bermain berbagai macam permainan. Bermain dapat memberikan pengaruh yang besar terhadap perkembangan kejiwaan, sifat, dan khidupan sosial anak di masa yang akan datang. Bermain dapat mengajari anak mengurangi egosentris karena usaha bersaing dengan jujur, sportif, tahu akan haknya dan peduli dengan hak orang lain, sarana belajar berkomunikasi dan berorganisasi [1].

Saat bermain, secara tidak langsung anak akan belajar dari lingkungannya yaitu lingkungan sekitarnya. Anak akan melihat, meniru dan kemudian mengimplementasikan. Sehingga saat bermain, selain anak mendapatkan kesenangan maka anak juga dapat belajar melalui sebuah permainan dan mengimplementasikannya dalam kehidupan sehari-hari.
Dalam kegiatan bermain, banyak terdapat jenis-jenis permainan yang dilakukan setiap anak di daerah. Secara umum, terdapat dua jenis permainan yaitu permainan modern dan permainan tradisional. Permainan modern merupakan permainan yang lebih memberikan kemudahan bagi penggunanya dan merupakan hasil dari kemajuan tekhnologi yang ada, pengguna hanya cukup duduk didepan monitor dengan menggunakan stick atau mouse sebagai alat untuk menjalankan permainan modern tersebut. Hal tersebut tidak lepas dari informasi yang didapat melalui media elektronik merupakan hasil dari peradaban manusia [2].

Berdasarkan informasi dari CNN Indonesia, seiring dengan perkembangan zaman, permainan tradisional memiliki saingannya sendiri yaitu permainan modern. Seiring dengan perkembangan zaman pula, permainan tradisional perlahan tidak dilirik lagi oleh generasi muda [3]. Namun, permainan tradisional merupakan aset bangsa yang perlu untuk dilestarikan. Permainan tradisional adalah suatu jenis permainan yang terdapat disuatu daerah tertentu yang berdasarkan kultur atau budaya daerah tersebut. Setiap daerah memiliki berbagai macam permainan tradisional yang berbeda-beda serta memiliki kekhasannya masing-masing. Terkadang didalam permainan tradisional memiliki kesamaan konsep hanya saja terdapat perbedaan nama atau bentuk meskipun sama pada dasarnya [4].

Permainan tradisional merupakan permainan yang telah dimainkan oleh anak-anak pada suatu daerah secara tradisi. Tradisi yang dimaksud ialah bahwa permainan tersebut telah diwariskan dari generasi yang satu ke generasi berikutnya. Permainan tradisional tidak mengeluarkan banyak biaya, baik 
untuk melatih fisik dan mental anak. Anak akan dirangsang kreatifitas, ketangkasan, jiwa kepemimpinan, kecerdasan, dan keluasan wawasannya melalui permainan tradisional [5]

Permainan tradisional memiliki berbagai manfaat terutama bagi anak-anak. Seperti pada penelitian yang menunjukkan bahwa anak-anak yang melakukan permainan tradisional jauh lebih berkembang kemampuan, termasuk kemampuan kerja sama, sportifitas, kemampuan membangun strategi, serta ketangkasan (lari, loncat, keseimbangan) dan karakternya [6]. Salah satu permainan yang masih dimainkan oleh anak-anak sampai saat ini adalah permainan lompat tali.

Permainan Lompat tali merupakan salah satu dari sekian banyak jenis permainan tradisional yang ada di Indonesia. Menurut Harsono dalam Febriani, mengatakan bahwa permainan tradisional lompat tali adalah permainan melompat dengan hali rintang berupa tali yang terbuat dari karet yang dirajut menjadi panjang [7]. Permainan lompat tali atau biasa disebut lompat tali merdeka, atau biasa yang lebih dikenal dikalangan umum yaitu permainan karet merupakan permainan yang mengandung unsur kompetisi, masing-masing kelompok atau team akan bersaing, bekerja sama, membentuk anggota untuk aktif dan dapat menaati peraturan bermain untuk mencapai tujuan kelompok .

Permainan tradisional lompat tali merupakan permainan yang sangat sederhana untuk dimainkan, namun dalam permainan tradisional lompat tali mengandung nilai-nilai yang sangat baik untuk ditanamkan dalam diri anak. Pengembangan karakter dalam diri siswa sangat penting untuk menjadi individu yang lebih baik dan mengerti akan nilai-nilai yang berlaku.

Permainan tradisional seringkali dimainkan dengan cara berkelompok. Dengan demikian, Kerjasama akan menjadi hal penting dalam permaian. Menurut Tenner dan Detoro, team works is a group of individuals working together to reach a common goal, yang dapat diartikan bahwa untuk mencapai tujuan akan lebih mudah diperoleh dengan melakukan kerjasama tim daripada dilakukan sendiri [8]. Hal ini diperkuat oleh Gaspersz yang mengungkapkan bahwa factor yang sangat penting dari suatu organisasi adalah keterlibatan anggota kelompok secara penuh karena setiap individu memiliki tingkat kemampuan yang yang saling mendukung [9].

Mengingat pentingnya nilai karakter Kerjasama, maka perlu adanya kegiatan yang dapat membentuk pengembangan nilai karakter tersebut salah satunya dapat dilakukan dengan pemberian layanan Bimbingan dan Konseling. Hal tersebut diperkuat bahwa posisi Bimbingan dan Konseling merupakan salah satu wadah dalam pembentukan karakter dalam sudut pandang teori sistem ekologis dari Bronfenbenner sebagai salah satu aspek yang mempengaruhi interaksi individu dalam proses kehidupannya [10].

Layanan bimbingan konseling dapat dilakukan melalui media Bimbingan Konseling. Permainan tradisional lompat tali dapat dijadikan sebagai media dalam layanan BK. Sudjana \& Rivai dalam Arsyad mengemukaan manfaat penggunaan media adalah proses pemberian layanan akan lebih menarik, memungkinkan siswa dapat menguasai dan mencapai tujuan layanan, metode dalam pemberian layanan akan lebih bervariasi, dalam proses pemberian layanan siswa dapat melakukan kegiatan mengamati, melakukan, mendemostrasikan, memerankan, dll, tidak hanya mendengarkan [11]. Selanjutnya, guru BK memiliki andil dalam pembentukakn nilai karakter melalui layanan BK.

Menurut Mursalin dalam Irawan menyatakan bahwa Guru bimbingan dan konseling sebagai salah satu personil pelaksana layanan, memiliki tanggung jawab yang besar terhadap profesinya atas keberhasilan pelaksanaan layanan bimbingan dan konseling di sekolah, sehingga sesuai fungsi Konselor di SD adalah sebagai konselor kunjung, maka permainan tradisional lompat tali perlu diaplikasikan dan diteliti untuk melihat peningkatan sikap Kerjasama siswa [12].

\section{METODE}

Penelitian yang dilakukan menggunakan penelitian kualitatif. Jenis penelitian ini termasuk dalam Ethnography Reserch, yaitu melakukan studi terhadap budaya kelompok dalam kondisi yang alamiah melalui observasi [13]. Populasi adalah siswa sekolah dasar, dengan sampel sebanyak yang terbagi dalam 50 kelompok. Teknik pengumpulan data melalui observasi langsung, yaitu mengamati langsung perilaku dan sikap siswa saat bermain lompat tali, sehingga instrument pengumpulan data yang di gunakan adalah pedoman observasi. Teknik analisis data yang digunakan adalah analisis deskriptif, yaitu menganalisis setiap catatan atau informasi yang didapatkan dari permainan lompat tali yang dilakukan oleh siswa terkait dengan sikap kerjasama siswa SD.

\section{HASIL DAN PEMBAHASAN}

Hasil penelitian yang dilakukan melalui observasi dan wawancara mengenai pengaplikasian permainan tradisional lompat tali terhadap sikap kerjasama siswa SD diuraikan atau dideskripsikan sebagai berikut.

Sikap kerja sama siswa yang ditampilkan tampak pada aktivitas dalam bermain lompat tali diantaranya:

1) Siswa melakukan kegiatan yang sama atau satu tujuan

a) Setiap kelompok memiliki tujuan untuk menang sehingga mengatur berbagai strategi untuk menjadi pemenang

b) Setiap anggota kelompok membangun kerjasama agar dapat melakukakn kegiatan yang sama sehingga dapat menjadi pemenang

2) Siswa terlihat bahu membahu bekerja sama

a) Setiap anggota kelompok saling menolong anggota kelompok yang gagal dalam permainan

b) Anggota kelompok yang berhasil berjuang untuk melanjutkan permaianan secara maksimal sehingga mendapatkan tujuan untuk menjadi pemenang

3) Siswa dapat mengatur pembagian tugas Bersama

a) Adanya leader / pemimpin dalam setiap anggota kelompok

b) Setiap leader membagi tugas dan bersama anggota kelompok bekerjasama menjalankan tugasnya masing-masing sesuai pembagian tugas

4) Siswa saling berkomunikasi satu sama lain

a) Anggota kelompok berkomunikasi dengan Bahasa verbal maupun nonverbal 
b) Setiap anggota kelompok berkomuniasi dengan salah satu diantara anggota kelompok lainnya untuk mengatur strategi permainan.

5) Siswa bertanggung jawab dengan menyelesaikan pekerjaan/kegiatan

a) Setiap anggota kelompok menjalankan tugasnya dengan penuh tanggung jawab

b) Setiap anggota kelompok bermain dengan maksimal dan sedaya upaya yang mereka bisa.

6) Siswa berkerja sama tanpa memandang strata (kelas)

a) Permainan dimainkan oleh anggota kelopok yang tidak ditentukan oleh kelas

b) Setaip kelopok terdiri dari kelas yang berbeda dan mereka dapat saling bekerjasama.

Hasil penelitian menjelaskan bahwa aplikasi permaianan tradisional dapat diimplikasikan dalam layanan Bimbingan Konseling, dan yang memperlihatkan adanya atau munculnya sikap-sikap kerjasama siswa SD.

Aplikasi permainan tradisional lompat tali dapat dijadikan sebagai media dalam layanan Bimbingan Konseling. Beberapa penelitian terkait dengan pengembangan dan pengaruh media permaian dalam layanan BK. Penelitian yang dilakukan oleh

Dari hasil analisis yang telah diperoleh, memberikan kontribusi bahwa dalam permainan tradisional memiliki manfaat yang besar pada kerja sama siswa. Hasil tersebut sejalan dengan hasil penelitian Hidayat yang mengatakan bahwa terdapat peningkatan kemampuan kerja sama siswa dalam permainan tradisional sebesar 81\% [14]. Hal tersebut sejalan dengan hasil observasi yang dilakukan yaitu saat bermain permainan tradisional anak saling membantu saat mengetahui teman tidak dapat melompati tali saat bermain lompat tali, sehingga terlihat anak saling bekerja sama saat bermain.

Hasil penelitian juga didukung oleh penelitian Sukma yang mengatakan bahwa terdapat pengaruh yang signifikan pada permainan tradisional lompat tali terhadap kerja sama siswa dalam pembelajaran [15]. Hal tersebut membuktikan bahwa dengan bermain permainan tradsional, nilai karakter kerja sama siswa akan tumbuh dan sangat berpengaruh pada proses pembelajaran anak di sekolah. Sesuai dengan aspek dalam indikator kerja sama yaitu saling membantu, berinteraksi dan bertanggung jawab. Dengan demikian saat pembelajaran anak akan terlatih untuk bekerja sama saat belajar kelompok atau tugas kelompok dan lain sebagainya.

\section{KESIMPULAN}

Simpulan dari hasil penelitian pengaplikasian permainan tradisional lompat tali terhadap sikap kerjasama siswa adalah siswa memiliki tujuan yang sama dalam mencapai tujuan, terlihat sikap saling membatu, adanya sikap mentaati aturan permainan, adanya saling komunikasi antar anggota kelompok, memiliki rasa tanggung jawab kebersamaan, saling membaur satu sama lain tanpa memandang perbedaan, adanya pembagian tugas dalam kelompok.
DAFTAR PUSTAKA

[1] Nur, H. (2013). Membangun Karakter Anak Melalui Permainan Anak Tradisional. Jurnal Pendidikan Karakter, (1).

[2] Kusumawardani, S. P. (2015). Game Online Sebagai Pola Perilaku (Studi Deskriptif Tentang Interaksi Sosial Gamers Clash Of Clans Pada Clan INDO SPIRIT). Jurnal Antropologi FISIP Universitas Airlangga, 4(2), 154-163.

[3] CNN Indonesia. (2018). Upaya Menjaga Permainan Tradisional di Era Modern. https://www.cnnindonesia. Diakses 1 Januari 2019.

[4] Zaini, M. . (2017). Permainan Tradisional Lompat Tali Merdeka Sebagai Media Pelaksanaan Proses Game Stage di SD Negeri 94 Pekanbaru. Jurnal Online Mahasiswa Fakultas Ilmu Sosial dan Ilmu Politik Universitas Riau, 4(2), 1-15.

[5] Agni, B. S. (2016). Permainan Tradisional Menjaga Warisan Di Penghujung Senja. Gelar: Jurnal Seni Budaya, 13(2).

[6] Yudiwinata, P. (2014). Permainan tradisional dalam budaya dan perkembangan anak. Jurnal Paradigma, 2(3).

[7] Febriani, E. (2015). Upaya Meningkatkan Pengembangan Motorik Kasar (Melompat) Anak Melalui Permainan Lompat Tali Pada Kelompok B TK Al-Hidayah Palaosan Tahun Pelajaran 2015-2016. Prosiding Ilmu Pendidikan, 1(2).

[8] Tenner, A.R. dan DeToro, I.J. (1992). Total Quality Management : Three Stepps To Continuous Improvement. Reading, MA: AddisonWesley Publishing Company.

[9] Gaspersz, V. (2001). Total Quality Management. Gramedia Pustaka Utama, Jakarta.

[10] Edmawati, M. D., \& Ahsan, S. (2017). Pendidikan Karakter Dalam Bimbingan Dan Konseling Berorientasi Pada Psychological Well Being Siswa. Prosiding Seminar Bimbingan dan Konseling, 1(1), 258-266.

[11] Arsyad, A. (2016). Media Pembelajaran. Edisi Revisi. Jakarta: Pt Raja Grafindo Persada.

[12] Irawan, F. (2015). Layanan Dasar Bimbingan Dan Konseling Melalui Weblog. Bandung: Universitas Pendidikan Indonesia

[13] Sugiyono (2014). Metode Penelitian Campuran. Bandung. Alfabeta.

[14] Hidayati, W. (2014). Upaya Meningkatkan Kemampuan Kerjasama Melalui Permainan Tradisional Pada Anak Kelompok A TK Aba Ledok I Kulon Progo Tahun Ajaran 2013/2014. Tidak Diterbitkan. Skripsi. Universitas Negeri Yogyakarta.

[15] Sukma. (2017). Pengaruh Pemberian Permainan Tradisional Terhadap Kerjasama Siswa Dalam Pembelajaran Pendidikan Jasmani, Olahraga, Dan Kesehatan (Studi Pada Siswa Kelas X Mipa SMA Negeri 2 Ponorogo). Jurnal Pendidikan Olahraga Dan Kesehatan, 5(2). 